\title{
Issues and Challenges in Spatial and Temporal Water Allocation in the Nile Delta
}

\author{
Wouter Wolters ${ }^{1, *}$, Robert Smit ${ }^{2,+}$, Mohamed Nour El-Din ${ }^{3, \dagger}$, Eman Sayed Ahmed ${ }^{4, \dagger}$, \\ Jochen Froebrich ${ }^{1,+}$ and Henk Ritzema ${ }^{5,+}$ \\ 1 Alterra, Wageningen University and Research, P.O. Box 47, 6700 AA Wageningen, The Netherlands; \\ jochen.froebrich@wur.nl \\ 2 Central Directorate for Water Resources, National Water Resources Unit, \\ c/o Ministry of Water resources and Irrigation, Corniche El Nil, Imbaba, 12666 Giza, Egypt; \\ robert.smit@wur.nl \\ 3 Irrigation \& Hydraulics Department of the Faculty of Engineering, Ain Shams University, 1 El Sarayat Street, \\ Abbasseya, 11566 Cairo, Egypt; mhmdnour2@gmail.com \\ 4 Planning Sector, Ministry of Water Resources and Irrigation, Imbaba, 12666 Giza, Egypt; \\ eman_sayed@hotmail.com \\ 5 Water Resources Management Group, Wageningen University, P.O. Box 47, 6700 AA Wageningen, \\ The Netherlands; henk.ritzema@wur.nl \\ * Correspondence: wouter.wolters@wur.nl; Tel.: +31-317-486-596; Fax: +31-317-419-000 \\ + These authors contributed equally to this work.
}

Academic Editor: Marc A. Rosen

Received: 9 March 2016; Accepted: 13 April 2016; Published: 19 April 2016

\begin{abstract}
Egypt is a gift of the Nile," wrote Herodotus, and indeed, without the Nile there would be no Egypt as the world knows it. Egypt is mainly dependent on the flow in the Nile River (with an agreed share of $55.5 \mathrm{BCM}$ ) and it receives about $1.3 \mathrm{BCM}$ rainfall annually (mainly along the north coast). The overall water use efficiency is already high, due to e.g., water scarcity and reuse of drainage water. Egypt's water resources are managed by the Ministry of Water Resources and Irrigation (MWRI), with agriculture as by far the largest user of irrigation water, with a share of about $85 \%$. The purpose of the paper is to discuss the major issues and challenges in the spatial and temporal allocation of water, in relation to a free cropping pattern and the characteristics of the irrigation system. We conclude that the current world-wide call for "crop-demand-based precision irrigation supply" will not be easily attainable in Egypt. Instead, "water security" in the form of "guaranteed or agreed" water supply may be a preferred water allocation aim for various reasons, including lack of large storage possibilities, impossibility of fine-tuning supplies in the system, and the needed capacity to deal with (future) droughts. Although the paper concentrates on technical issues, it is increasingly realized that the challenges are not only of a technical nature and that there is a need for integration of policies as well as a need to establish effective science-business-policy interfaces at the national level.
\end{abstract}

Keywords: irrigation system; spatial and temporal water allocation; crop-demand-based water supply; drought; agriculture; integration of policies; water scarcity

\section{Introduction}

\subsection{Egypt Is a Gift of the Nile}

The Nile River Basin is, like the Indus basin, one of the oldest agricultural areas in the world [1] Egypt is an arid country with abundant sunshine and fertile soils, but rainfall is very scarce, thus agriculture has always depended upon irrigation. Average annual rainfall ranges from $1.5 \mathrm{~mm}$ 
in the south (near Aswan, about $900 \mathrm{~km}$ south of Cairo) to $150 \mathrm{~mm}$ in the north (in the coastal regions bordering the Mediterranean Sea, about $150 \mathrm{~km}$ north of Cairo. However, Egypt is blessed with the River Nile that provides $94 \%$ of the total water resources and $97 \%$ of the renewable water resources. There are limited quantities of water from rainfall and deep groundwater. These deep groundwater resources are mostly non-renewable and must therefore be used prudently with a long-term planning horizon.

The water provided by the Nile, combined with fertile soil and favorable climate, enables farmers to achieve relatively high crop yields. The agricultural sector provides employment to $32 \%$ of Egypt's work force and contributes about 14\% of GDP to Egypt's economy [2].

Egypt's dependence on the river Nile is also illustrated by the fact that about $90 \%$ of the population lives on $5 \%$ of the land area around the Nile River and Delta. The remaining $95 \%$ of the country is desert area. The natural flow of the Nile has its annual peak in the summer and is subject to considerable variations over the years, depending mainly on the rainfall at the Ethiopian plateau. These variations tend to come in successive years of high or low floods. These multi-year cycles of high and low river flows were reason for Egypt to build the Aswan reservoir with sufficient storage to hold the excess water of high-yield years and use it in low-yield years.

\subsection{Egypt's Water Resources Management/Development and Planning}

From the days of the Pharaohs until the 19th century, basin irrigation was practiced. For this ancient method, based on the natural regime of the Nile, the natural drainage capacity of the land was sufficient to protect the area against the twin problem of waterlogging and salinity. In the 19th century, new crops, i.e., cotton and sugarcane, were introduced that required water when the Nile's natural water levels were low. This resulted in the construction of barrages in the River Nile and a network of irrigation canals and open drains. The design was based on the British design school, based on the principle that the operation of such a large system had to be simple, run by as few people as possible and at the lowest cost [3]). With the construction of barrages in the River Nile and a network of irrigation canals, a continuous (day and night) fixed flow to a known area without the need for regular adjustments was achieved by gravity. Farmers were expected to handle their ration efficiently whenever it came, even at night. Adapting water gifts to changing demands in order to increase harvest was not done. With the completion of the High Aswan Dam in 1970, the Nile flow is now completely controlled. The High Aswan Dam (HAD) also enabled Egyptian farmers to move from seasonal to year-round irrigated cropping. Nowadays, the main crops are cotton, sugarcane, and paddy in the summer and wheat and berseem (Egyptian clover) in the winter. Land holdings are small, with about $78 \%$ less than 2.0 ha [4]. The year-round irrigation boosted agricultural production, but also made it necessary to install subsurface drainage systems to prevent salinization of the soil. Since the 1970s, the Egyptian Public Authority for Drainage Projects (EPADP, part of the Ministry of Water Resources and Irrigation) has installed almost 3.4 Mha with subsurface drainage systems $[5,6]$. The first dam near Aswan was built in 1903. The more recent planning of Egypt's water resources is based on the 1959 Nile Water Agreement, which allocates 55.5 billion cubic meters per year to Egypt. However, this international water agreement is no longer recognized by all riparian countries, some of whom demand a larger share of the Nile water to develop their economies.

The water balance of the country shows that agriculture is by far the largest consumer of water, with about $84 \%$ of the available water resources. The drinking water sector consumes $12 \%$ and industries consume $4 \%$. To make up for water shortages, drainage water is recycled either directly by pumping it back into the Nile, into irrigation canals, or by pumping shallow groundwater in the Nile valley and delta. Reuse is practiced at the farm level, project level, and regional level, often as a combination of official reuse by the government and unofficial reuse by individual farmers. All these reuse options have increased Egypt's water availability by $20 \%$ [7]. At present only $22 \%$ of the fresh Nile water released from HAD reaches the Mediterranean Sea as drainage water. Together with water losses through evaporation from Lake Nasser, which are estimated to range from 10 to 
$15 \mathrm{BM}^{3}$ per year $[8,9]$, the total water losses are about $26 \%$. The overall water use efficiency is very high (about $80 \%$ ), especially as we consider that drainage outflow to the sea is close to the minimum amount necessary to prevent saline water intrusion from the Mediterranean Sea and to sustain soil fertility of the Northern lands of the Nile Delta [10]. There is a general belief that through irrigation modernization large amounts of water can be saved through a switch to more efficient irrigation systems and infrastructure [11].

The purpose of this paper is to highlight the current major issues and challenges in the spatial and temporal water allocation in the Nile Delta. These issues and challenges are especially important in light of the free cropping pattern in Egypt and the characteristics of the irrigation system. The cropping pattern used to be dictated by the government but now farmers are free to grow the crops they like, which obviously gives rise to allocation issues. In addition, the characteristics of the system as well as the very limited possibilities to carefully adjust water supplies do not allow "crop-demand-based precision irrigation supply." We will also briefly compare with other "typical" irrigation systems in the world.

It is increasingly realized that the challenges are not only of a technical nature. The issue of water scarcity has consequences and implications that can no longer be adequately addressed by any one of the Ministries alone. There is a need for integration of policies and a need for trans-disciplinary approaches that should evolve in a "Water Scarcity Action Plan" as well as an effective science-business-policy interface at the national level. Food is grown by the private sector (including large farming organizations and small farmers) and this important stakeholder has a prime position in the Egyptian irrigation system (and its new extensions).

\section{Major Overall Challenges for Egypt}

\subsection{An Ever-Increasing Pressure on Egypt's Water Resources}

For decades Egypt's population grew by $2 \%$ annually; it has now reached approximately 90 million people. The fresh water availability per capita is closely related to the population growth and has decreased, as shown in the following Table 1:

Table 1. Trend of per capita fresh water availability.

\begin{tabular}{ccc}
\hline Year & Population & Nile Water Availability \\
\hline 1960 & 25 million & $2200 \mathrm{~m}^{3} /$ capita/year \\
2000 & 62 million & $887 \mathrm{~m}^{3} /$ capita/year \\
2010 & 80 million & $688 \mathrm{~m}^{3} /$ capita/year \\
2015 & 90 million & $611 \mathrm{~m}^{3} /$ capita/year \\
2037 & 140 million & $392 \mathrm{~m}^{3} /$ capita/year \\
2050 & 170 million & $324 \mathrm{~m}^{3} /$ capita/year \\
\hline
\end{tabular}

Source: [12] (National Water Resources Plan 1997-2017).

Due to its population growth, Egypt is increasingly becoming a water-scarce country. Egypt's present population is approximately 90 million people, each of whom has a water share of 616 cubic meters per year, which is below the UN water-poverty criterion of 1000 cubic meters per capita per year. In order to feed its growing population, Egypt needs to boost its agricultural production [13], which can be done by e.g., developing non-conventional water resources (including reuse of drainage water, use of brackish water, desalination of sea water, and water harvesting in wadis) and increasing water productivity, by increasing yields per unit of water used (more crop per drop) and increasing the value of the water used (more cash per splash). Importing food is another way of solving the water shortage (virtually increasing the water supply) [14]. 


\subsection{Water Pollution}

Pollution of the surface water by agricultural drainage water, industrial wastewater and domestic solid waste and wastewater is a serious threat to the quality of irrigation and potable water supply [15]. While $99 \%$ of households are connected to a potable water supply system and $80 \%$ of the urban population is connected to public sewerage systems, in rural areas sewerage and solid waste services are largely absent. Only $26 \%$ of rural households are connected to public sewerage systems. The poor surface water and shallow groundwater quality in the Nile Delta forms a serious health risk through the reuse of drainage water and pumping of contaminated groundwater. It also frustrates government plans for downstream reuse of drainage water, which is a key element in its strategy to cope with water scarcity.

The National Water Resources Plan [12] formulates the key questions on water quality, health, and environmental aspects as follows: (i) what is the best mix of prevention, treatment and protection measures that results in a water quality that complies with reasonable standards?; and (ii) what is the level of investment needed to provide all people with safe drinking water and adequate sanitation facilities?

\subsection{Effect of Climate Change}

Studies show that the Middle East and North Africa (MENA) region will be one of the areas most affected by climate change. For Egypt this means that: (i) the low-lying Nile Delta will be threatened by seawater rise [16]; (ii) more extreme fluctuations in the Nile flows are anticipated [17]; and (iii) there will be an increased water requirement due to higher temperatures [18]. To date, there is no certainty about whether the Nile flow to Egypt may decrease or increase. The Egyptian share of the Nile flow of $55.5 \mathrm{BCM}$ is about $5 \%$ of the $1660 \mathrm{BCM}$ total rainfall in the entire Nile Basin. With $85 \%$ of the Nile flow originating in the Ethiopian highlands, it is clear that the future Nile flows depend for a large part on the impact of climate change on the rainfall in Ethiopia.

The overall sensitivity of the Nile River flow in response to changes in rainfall is considerable: if throughout the Basin rainfall were to decrease by $10 \%$, inflow into Lake Nasser would decrease by more than $30 \%$. Similarly, a small increase in rainfall will result in a significant increase in inflow [18]. The sensitivity of the Nile Basin to changes in rainfall is also observed in the historical data. For example, during the early 1980s the flow into Lake Nasser was $40 \%$ lower than during the late 1990s, while the difference in rainfall between the two periods was only $10 \%$.

\subsection{Effect of Urbanization and Infrastructure in the Delta}

With some $50 \%$ of the Egyptian population living in the Nile Delta, the delta comprises many cities and towns. Furthermore, industry is a growing sector in the national economy. Further industrial development is expected to play a major role in the socioeconomic development of the country, providing employment for a large part of the growing population. Although the industrial policy is to create new cities and industrial zones outside of the Nile Valley and Delta, there is still a lot of industrial development in the delta as well. Moreover, through a rapidly spreading informal urbanization [19], there is increasing land fragmentation [20], which has an indirect effect on the water system. The extensive urban network of cities, villages, and connecting roads influences the irrigation networks due to excessive fragmentation. In addition, the increasing number of people living in urban environments in the delta are less aware of their huge and continuing dependence on water. It is also true that urban environments require less water than agricultural land. In summary, there is enormous pressure on both the quality and quantity of water in the delta, resulting from intensifying agriculture, rapidly growing industry, and a rapidly growing population. It is sometimes argued that if the current trends continue, the Delta will be a predominantly urban environment in 50 years from now. 


\subsection{Current Water Policy to Face the Challenges}

The main challenge will be deciding how Egypt can safeguard its water resources in the future under the conditions of a growing population and more or less fixed water availability. Assuming that all available additional resources will be developed, the main questions with respect to water quantity that have to be answered are [12]:

- How can the efficiency of the various uses be increased?

- How can the agricultural expansion policies of the government be supported and what are the priorities and limitations in this expansion, given the existing water resources, optimum efficiency, and the priority for drinking and industrial water use?

- How should Egypt manage its water resources system under variable supply conditions?

Egypt's National Water Resources Plan [12] is based on a strategy that has been called "Facing the Challenge." This includes measures to

(1) develop additional resources,

(2) make better use of existing resources, and

(3) measure water quality and environmental protection in the field.

There are various large programs ongoing in the Nile Delta to "face the challenge," including the Integrated Irrigation Management Improvement and Management Project (IIIMP); Enhanced Water Resources Management Project (EWRMP); the Second National Drainage Project (NDP2); the Integrated Sanitation and Sewerage Infrastructure Project (ISSIP); Improved Water Supply and Sanitation Services (IWSP); and the On-Farm Irrigation Development Project in the Old Lands (OFIDO).

\subsection{Need for Integration of Policies}

Future water allocation will have to be done keeping all water-using sectors in mind. The overall priority sequence is: first drinking water, then industry, and whatever is remaining will be available for agriculture and nature. The main option available in the short term to reduce water scarcity in the priority sectors of the economy is to allocate less to the agriculture sector [21]. However, the issue of water scarcity has consequences and implications that can no longer be adequately addressed by any one of the Ministries alone. Many other government departments and agencies must be involved and decisions will have to be made at the highest political level [22].

All policies in Egypt must be conscious of the severe limitations in water availability, and water policies need to address technological developments as well as the full range of other issues, including: macro-economic factors, economic issues that influence farm-level decisions, development of human capital, governance, and financial risk management. The government will be well equipped to deal with future uncertainties if it prepares a "scarcity outlook" that addresses the situation in 2050, and implements a "Water Scarcity Action Plan" [22] that will incorporate the knowledge that reform decisions are inherently political, that non-water policies are central to water management, and that improved accountability of government agencies and water service providers to the public is essential.

\section{Issues and Challenges in Spatial and Temporal Water Allocation}

\subsection{Aggravation of the "Seven Fat Years and Seven Lean Years" Phenomenon}

The "seven fat years and seven lean years" phenomenon refers to the cyclic rhythm of the Nile flows in existence for thousands of years. The construction of the High Aswan Dam dampened this effect for Egypt, but the inflow of Lake Nasser is still subject to this variation and it needs to be mentioned that the construction of dams upstream in the Nile basin is expected to have a big impact on the flow to Egypt [23] and consequently also to the Nile Delta. The last major drought (period of 
lean years) was in the mid-1980s, but in the future droughts are predicted to become more severe, not only because of climate change but also because of the development of water resources upstream in the Nile Basin.

\subsection{Description of the Irrigation System in the Nile Delta}

As part of the overall system fed from the High Aswan Dam, the main canals operate essentially under a system of upstream control, with each irrigation directorate receiving a seasonally varied supply determined centrally by the Irrigation Sector in accordance with the expected cropping pattern. Releases from High Aswan Dam are made according to the predicted water requirements and taking into account the considerable travel time (measured in weeks) from Aswan to the Delta.

Control of discharges in the main canals takes place at the head regulators and at cross regulators located at the boundaries between irrigation directorates. The regulators are mostly equipped with lifting gates. Discharge control depends on rating curves either for the gates or for the downstream channel; these ratings are confirmed by periodic calibration through current metering. The method of operation emphasizes regulation to achieve specified water levels downstream of the regulators (as a proxy for discharge), rather than to maintain particular upstream water levels [1]. Upstream water levels at cross regulators may vary depending both on the season and on which branch canals are being fed from the upstream reach at any particular time under the rotation schedule: operation of the traditional irrigation system is based on rotational water deliveries to individual branch canals. The main feeder canals flow continuously and the off-taking branch canal head regulators are opened according to a rotation schedule, consisting of, e.g., a three-turn rotation or five days on/10 days off in winter and a two-turn rotation or five days on/five days off in summer. Because farmers lack confidence in the upstream control-rotational irrigation system they tend to over-irrigate, particularly head-end farmers, as an insurance against the uncertainty of the irrigation water supply [24]. Thus, they reduce water availability to tail-end farmers who, in turn, adopt a coping strategy that involves the reuse of drainage water even if it is saline (so-called "unofficial reuse").

Branch canal head regulators are generally also equipped with lifting gates, and again regulation of water deliveries is achieved by adjusting gates to maintain target downstream water levels. These target levels vary seasonally and serve as an indirect and rather approximate means of controlling discharges; in practice, they are determined to a large extent on the basis of accumulated experience.

\subsection{Management of Water in the Nile Delta}

In the absence of explicit measurement of discharge, the District Engineer, with the gate operator (bahar) who does the day-to-day control of the regulator gate, can exercise a certain amount of flexibility and discretion in allocating water supplies [1]. Sometimes, gate opening and rotation schedules may be adjusted in response to representations and complaints from farmers, or to observed conditions, e.g., the occurrence of escape flows at canal tails. In effect, the staff who are responsible for arranging water deliveries to individual branch canals try to distribute the water allocated to them in order to achieve the greatest possible degree of satisfaction of users. It is important to note that the irrigation system is supply-oriented at the upstream side, and demand-oriented at the downstream side. Obviously this is creating management issues.

It is also important to note that in managing water deliveries under the rotation system, operating staff are able to adjust not only the flow rate, but also the flow duration, by adding or subtracting days from the "on-period." This ability to use time as an operating variable allows operating staff to compensate for any surpluses or deficits arising from the imprecision of the discharge regulation, and in particular to deal with "emergency" shortages on individual canals. One adaptive practice that has been applied in recent years, especially during the peak period in rice areas, is the so-called "focused flow" [1], which involves concentrating the share of water from two or three canals into one canal at a 
time to ensure that water reaches the tail. Nevertheless, this cannot be done accurately as there is no volumetric control.

Downstream of branch canal offtakes, there is usually only limited hydraulic regulation. Except where they are needed for internal rotation or to control steps in water level, gates on cross regulators and sub-branch canal offtakes are often not functional or have been removed. Water levels depend primarily on abstraction of water by farmers.

\subsection{Advantages of Improvements in Flow Regulation Being Tested}

Due to certain negative effects of the rotational system, improvements are being tested [1]. These negative effects include: (i) non-flexibility in matching irrigation intervals and crop or soil condition; (ii) small effective channel storage capacity; (iii) high side slope deterioration during off periods and low bank stability; and (iv) the high cost of big hydraulic sizes of canal cross sections and structures.

The advantages of continuous flow compared to the rotation system are numerous in the opinion of both the users and the operators. The various advantages and their impacts found [1] in the tests of summer 2015 include, but are not limited to, (i) water availability at the tail of the canal is improved, and as an indicator of this both farmers and Irrigation Sector staff state that the number of complaints from tail users is drastically reduced; (ii) all parties emphasize that the irrigation practices can be adjusted to the water requirements of the crops rather than to the availability of water in the canal; (iii) another important advantage is that farmers in the tail reach can now develop irrigation strategies to reduce the salinity of the soil by reducing the reuse of drainage water and practicing leaching of saline soils through rice cultivation or in the period between two crops; and (iv) an advantage for water management is that farmers can use irrigation water efficiently. Under the rotation system farmers' priority was getting sufficient water, or more, because too much water is still better than too little water.

There are some cautions with these conclusions, because although the findings are encouraging (favoring continuous flow), these results may be misleading as (1) it was impossible to know the exact water volumes delivered to the canal during the whole season; and (2) the irrigation District did not receive complaints regarding water shortage during the 2015 summer season. This might indicate that supplied volumes of water to the canal were (too) generous.

\subsection{The Mostly Unknown Role of Groundwater}

A recent phenomenon of groundwater development and abstraction has been unfolding over the last few years largely under the radar of the water management staff in the Delta. Data about current groundwater abstraction levels in the Nile Delta are lacking and there are contradictions regarding the total irrigated area with groundwater in published data.

A recent study [25] found that: (1) groundwater use in the Nile Delta is a poorly studied phenomenon; few if any studies were concerned with the socioeconomic impact of using groundwater in old lands of the Nile Delta; (2) most of the wells are shared between various farmers: this shows that individual needs are still limited and seldom justify individual investment in a well (although this latter case is growing); (3) pumping from a well requires more energy than pumping from waterways, and costs on average 2 to 3 times more than pumping from the canal, with irrigation durations around twice as long too; (4) drilling and constructing a well costs around EP 11,000; and (5) these wells are in general only used intermittently and it is not always easy to assess the frequency of use by farmers. Farmers mostly use these wells in the summer (June and July).

Some farmers mentioned that they rely mainly on wells by a ratio of $70 \%-100 \%$ for irrigation in the summer season. Although conjunctive use may be seen as the key to flexibility and increasing supply to farmers, it is likely to increase sharply if overall supply has to be reduced, for whatever reason. The possible impacts of such a sharp rise would include: (i) a drop of dynamic water table level under $10 \mathrm{~m}$; (ii) increased salinity locally; and (iii) increased saline groundwater intrusion. 


\section{Discussion}

In this section the issues and challenges are briefly discussed. It is increasingly realized that the challenges are not only of a technical nature.

\subsection{No Real Possibility of Regulating Water Volumes}

Discharge to main canals depends on rating curves either for the gates or for the downstream channel; these ratings are highly inaccurate (only confirmed by periodic current metering) [1]. This method attempts to achieve specified water levels downstream of the regulators as a proxy for discharge. For branch canals regulation of water deliveries is again achieved by adjusting gates to maintain target downstream water levels. These target levels vary seasonally and serve as an indirect and rather approximate means of controlling discharges; in practice, they are determined to a large extent on the basis of accumulated experience and this does not give insight into the volumes supplied.

\subsection{Matching Irrigation Supply with Crop Demand Currently Impossible}

The main canals operate essentially under a system of upstream control, with each irrigation directorate receiving a seasonally varied supply determined centrally by the Irrigation Sector in accordance with the expected cropping pattern. However, the farmers are free to choose their crops. The most basic requirements for crop-demand-based operation of an irrigation system include (1) the availability of variable quantities of water during the cropping seasons and (2) the possibility of, somehow, regulating the flows/volumes.

Tests to reduce the non-flexibility in matching irrigation intervals and crop or soil condition are being carried out in Egypt, but are hampered by the fact that the cropping pattern is not known and the flows/volumes cannot be properly measured and regulated. In practice this means that hopes for a better match between irrigation supplies and demand remain futile until a more accurate regulation of the available volumes is possible, provided the water is available. Again, the irrigation system is supply-oriented at the upstream side, and demand-oriented at the downstream side. As crop-demand-based precision irrigation supply will not be easily attainable in Egypt, providing water security in the form of guaranteed or agreed water supply may be a preferred water allocation principle. Proportional division of flow may have the best chances as the basis for water allocation in periods of drought. Instead of dividing water over the area, the water shortage is then divided over the land. There is a lack of awareness about the need to develop the capacity to deal with droughts in the future.

This issue in itself is not new to Egypt; it is documented for the Delta and also for Fayoum. Although the overall irrigation efficiency in Fayoum is relatively high, the irrigation water is not uniformly divided over the area [26]. Measurements of discharges and the division of flow over Fayoum showed that the improvement of irrigation water management should begin upstream, at the system's main flow-division structures. Once adequate water supplies to the lateral command areas have been secured, improvements further downstream in the system can be of value.

\subsection{The Future Is Uncertain}

The last major drought (period of "lean" years) was in the mid-1980s but the value of the assets in the Nile Valley and Delta has increased considerably since the 1980s and so has the population of Egypt. A drought of similar proportions can be expected to have more serious consequences nowadays. Climate scientists insist that future Nile flows depend for a large part on the impact of climate change on the rainfall in Ethiopia [18]. It is also known that droughts are predicted to become more severe in the future, not only because of climate change, but also because of development of water resources upstream in the Nile Basin. "Lean" years will aggravate the effect of upstream developments. This clearly shows the importance of Egypt being able to deal with (future) droughts. Changes in the cropping pattern recommended to farmers will be one of the tools to adapt to drier years. 


\subsection{The International Water System Dimension}

The scale of the Egyptian water system is large and there are not many systems that are comparable in terms of size, importance, and type of users, i.e., predominantly serving small land holdings.

An example of a comparable system is the irrigation system of Pakistan, which was developed by the same school of engineers as in Egypt [3]. In Pakistan, water managers cannot achieve crop-demand-based supply of irrigation water for various reasons [27]. Both the capacity of the canal system, at low rates of typically between 1.8 and $2 \mathrm{~mm} /$ day (much lower than in Egypt) and the availability of water are not sufficient for crop-demand-based supply of irrigation water, with the existing capacity of the reservoirs fully utilized. Lake Nasser in Egypt provides inter-annual storage, whereas the major reservoirs in Pakistan (such as Mangla and Tarbela) only provide intra-annual storage. There is monsoon rainfall in Pakistan, but the travel times in the system and the spatial distribution of monsoon rains are such that these two cannot be matched: the water for a field in the south of the Punjab province is released about three weeks before it actually reaches the field. The conclusion for the system in Pakistan was that it would be better to improve the performance of the present water allocation, thereby providing an assured or guaranteed water supply to water users, than to respond to field-generated demand.

A well-known example of an accurately managed system where water can be supplied when and where it is required is the Société du Canal de Provence et d'Aménagement de la Région Provençale (SCP), in France. This SCP was established in 1957, on the initiative of the French Ministry of Agriculture, by three local authorities: the administrative districts of the Var and Bouches-du-Rhône, and the City of Marseille [28]. Its mission is to develop and manage regional water resources, in order to provide a safe and reliable water supply for agriculture, industry and domestic use. The SCP is totally different from the Egyptian irrigation system in terms of institutional setup, size, and users. It is a public company, with $85 \%$ of its equity capital held by local authorities in the Provence-Alpes-Côte d'Azur region and 15\% held by private partners (Chambers of agriculture and banks). It has about $200 \mathrm{~km}$ of main infrastructure including nearly $70 \mathrm{~km}$ of open canals and nearly $5000 \mathrm{~km}$ of supply and distribution pipes, with water coming from 85 dams and associated reservoirs. The relative abundance of rainfall and water storage capacity in the area combined with the possibilities of regulating the water flow accurately (because of the available head in the system) is the reason why water can be supplied when and where it is required.

\subsection{The Need for Transdisciplinary Approaches on the Way to Sustainability}

There is increasing insight that sustainable development requires fundamentally different approaches that do not only take into account the interaction of social, technical, and environmental systems [29], but also complexity and the uncertainties in decision-making as well as in the boundary conditions [30]. Trans-disciplinary approaches have emerged as powerful practices to shift from understanding sustainable challenges to developing socially robust orientations [31].

Understanding that uncertainty and complexity cannot be tackled by traditional deterministic methods, a stronger shared acceptance on possible solution strategies can be seen as the major driver to involve different sources of knowledge and extended peer communities (Spangenberg 2012). Of similar importance is the permanent process evaluation and co-learning during such a transdisciplinary approach [31].

Because there are many stakeholders in consuming and using water, it is clear that transdisciplinary approaches go far beyond traditional participatory approaches such as conducting interviews or farmer field days.

The implementation of such a transdisciplinary approach to improve the water management within the Nile Delta would primarily require a readiness to realize such a multi-stakeholder, multi-sector initiative, and a willingness to link effectively across different disciplines and policies. Food is grown by the private sector (large and small) and that sector needs to be involved as well. 
Secondly, it is important to realize that successful transdisciplinary approaches are often based in multi-annual pre-existing experience and a strong local facilitation capacity.

Understanding that there are a plethora of stakes in consuming and using the water of the River Nile, it is clear that implementing a true transdisciplinary approach in Egypt is not a trivial task and that it requires a serious commitment of all actors to cooperate over a longer period. To reach that, the presence of an adequate policy framework, institutional development, and the proper enabling environment is key.

In Egypt, policies and implementing institutions remain rather disconnected. There is a need for instruments that support the integration of policies and the integration of implementing steps. Without that, it will be difficult to foster cooperation between policy-makers and other stakeholders, including the food-producing private sector. Therefore, there is a need for effective science-policy-business interfaces at the national level. Understanding that all the past sector-oriented efforts have not led to final solutions and that there is not a really effective science-policy interface in operation may raise the expectation that using a transdisciplinary approach is worth trying. However, realizing the difficulty of integrating policies in Egypt, the sensitive political situation in the entire MENA region now and the limited local capacity to facilitate such a transdisciplinary approach suggests that for Egypt there is a need to tailor approaches specifically and to commit enough time to allow small success stories to grow.

\section{Conclusions and Recommendations}

- There is enormous pressure on both the quality and quantity of water in the Delta, resulting from intensifying agriculture, rapidly growing industry, and a rapidly growing population. The rapidly spreading informal urbanization, leading to an extensive urban network of cities, villages, and connecting roads, influences the irrigation networks due to excessive fragmentation.

- $\quad$ Egypt is an arid country with abundant sunshine and fertile soils, but virtually without rainfall. However, Egypt is blessed with the River Nile, which provides $94 \%$ of total water resources and $97 \%$ of renewable water resources. The water provided by the Nile, combined with fertile soils and favorable climate, enables farmers to achieve relatively high crop yields.

- The last major drought (period of "lean" years) was in the mid-1980s, but in future the droughts are predicted to become more severe, not only because of climate change but also because of development of water resources upstream in the Nile Basin. Not only has the value of the assets in the Nile Valley and Delta increased considerably since the 1980s, so has the population of Egypt. A drought of similar proportions can be expected to have more serious consequences nowadays. These issues make it crucial for Egypt to be able to deal with (future) droughts and other climate-related extreme events: there is a need to develop capacity for assessment and management of water and climate-related risks in the future.

- Matching irrigation supply with crop demand is currently impossible because there is no real ability to properly measure and regulate water volumes at the distributary canal level. Moreover, releases from the High Aswan Dam are made according to crop water irrigation water requirements from an estimated cropping pattern, while the actual cropping pattern is free.

- As crop-demand-based precision irrigation supply will not be easily attainable in Egypt, providing water security in the form of guaranteed or agreed water supply may be a preferred water allocation principle. Proportional division of flow may have the best chances as the basis for water allocation in periods of drought. Instead of dividing water over the area, the water shortage is then divided over the land. There is a lack of awareness about the need to develop the capacity to deal with droughts in the future.

- The issue of (future) water scarcity has consequences and implications that can no longer be adequately addressed by any one of the Ministries alone. Many other government departments and agencies must be involved and decisions will have to be made at the highest political level, requiring the integration of policies. There is a need for a "Water Scarcity Action Plan" as well as 
effective science-business-policy interfaces at the national level. It is important that all involved realize that food is grown by the private sector (including large farming organizations and small farmers) and this important stakeholder has a prime position in the Egyptian irrigation system (and its new extensions).

Acknowledgments: The authors would like to acknowledge the cooperation of many Egyptian and international water experts in their involvement in water management in Egypt, working in various projects over decades. The most recent projects include the various phases of the National Water Resources Plan projects, the Enhanced Water Resources Management Project (EWRMP), and the Egyptian-Dutch Advisory Panel Project (APP). Notwithstanding this, all opinions are those of the authors and do not necessarily represent the official views of any of those projects.

Author Contributions: Wouter Wolters and Henk Ritzema conceived the idea of sharing the issues and challenges in water allocation in the Nile delta in this paper. They combined their experiences in Egypt and other countries with Mohamed Nour El-Din, Eman Sayed and Robert Smit, who are now involved, all in their respective positions, in water resources planning in Egypt and who all have an intricate knowledge of the current conditions of water management in the Delta. Jochen Froebrich shared his experience mainly in the sections on the international dimension of the paper and more specifically his vast and up-to-date knowledge in the area of "green economic growth" and science-business-policy interfaces.

Conflicts of Interest: The authors declare no conflict of interest.

\section{References}

1. Enhanced Water Resources Management Project (EWRMP). Continuous Flow Implementation in Nekla Command Area, Summer, Final Report; MWRI: Cairo, Egypt, 2015.

2. World Bank Development Indicators. Available online: http://data.worldbank.org/data-catalog/worlddevelopment-indicators (accessed on 23 December 2015).

3. Ertsen, M.W. The Development of Irrigation Design Schools or How History Structures Human Action. Irrig. Drain. 2007, 56, 1-19. [CrossRef]

4. Abdel Dayem, S.; Abdel Gawad, S.; Fahmy, H. Drainage in Egypt: A story of determination, continuity, and success. Irrig. Drain. 2007, 56 (S1), S101-S111. [CrossRef]

5. Amer, M.H.; Abu-Zeid, M. History of Land Drainage in Egypt. In Land Drainage in Egypt; Amer, M.H., De Ridder, N.A., Eds.; Drainage Research Institute: Cairo, Egypt, 1989; pp. 43-66.

6. Fathi, M.; Hamza, A.M. Development of Land Drainage in Egypt and the Role of the Egyptian Public Authority for Drainage Projects. Drainage along the River Nile; Nijland, H.J., Ed.; Ministry of Public Works and Water Resources, Egypt, Ministry of Transport, Public Works and Water Management, Directorate-General of Public Works and Water Management: Lelystad, The Netherlands, 2000; pp. 21-51.

7. Barnes, J. Mixing waters: The reuse of agricultural drainage water in Egypt. Geoforum 2014, 57, $181-191$. [CrossRef]

8. El-Magd, I.H.A.; Ali, E. Estimation of the evaporative losses from Lake Nasser, Egypt using optical satellite imagery. Int. J. Digit. Earth 2012, 5, 133-146. [CrossRef]

9. Elsawwaf, M.; Willems, P.; Pagano, A.; Berlamont, J. Evaporation estimates from Nasser Lake, Egypt, based on three floating station data and Bowen ratio energy budget. Theor. Appl. Climatol. 2010, 100, 439-465. [CrossRef]

10. Ritzema, H.P.; Schultz, B. Optimizing subsurface drainage practices in irrigated agriculture in the semi-arid and arid regions: Experiences from Egypt, India and Pakistan. Irrig. Drain. 2011, 60, 360-369. [CrossRef]

11. Fader, M.; Shi, S.; von Bloh, W.; Bondeau, A.; Cramer, W. Mediterranean irrigation under climate change: More efficient irrigation needed to compensate increases in irrigation water requirements. Hydrol. Earth Syst. Sci. Discuss. 2015, 12, 8459-8504. [CrossRef]

12. MWRI. Water for the Future, National Water Resources Plan 2017. Available online: https://www. google.com/url?sa=t\&rct=j\&q=\&esrc=s\&source=web\&cd=1\&ved=0ahUKEwjb4-qIq5DMAhUCDSwKHU29 CGgQFggcMAA\&url=https\%3a\%2f\%2fjkbharris.files.wordpress.com\%2f2010\%2f09\%2fegypt-national-waterresources-plan-2017.pdf\&usg=AFQjCNFEeiZ-RTPF5uKkupnPWFmzShJXrw\&sig2=jIOSxoI0qaOYuePSv WUaHA\&bvm=bv.119408272,d.bGg\&cad=rja (accessed on 23 December 2015).

13. El-Agha, D.E.; Molden, D.J.; Ghanem, A.M. Performance assessment of irrigation water management in old lands of the Nile delta of Egypt. Irrig. Drain. Syst. 2011, 25, 215-236. [CrossRef] 
14. El-Gafy, I.K. System Dynamic Model for Crop Production, Water Footprint, and Virtual Water Nexus. Water Resour. Manag. 2014, 28, 4467-4490. [CrossRef]

15. Abdel-Dayem, S. Water Quality Management in Egypt. Water Resour. Dev. 2011, 27, 181-202. [CrossRef]

16. IDSC-UNDP. Egypt's National Strategy for Adaptation to Climate Change and Disaster Risk Reduction. Report by the IDSC, Information and Decision Support Centre of the Egyptian Cabinet and UNDP. Available online: http:/ / faolex.fao.org/docs/pdf/egy141200.pdf (accessed on 8 April 2016).

17. Sušnik, J.; Vamvakeridou-Lyroudia, L.S.; Baumert, N.; Kloos, J.; Renaud, F.G.; La Jeunesse, I.; Mabrouk, B.; Savić, D.A.; Kapelan, Z.; Ludwig, R.; et al. Interdisciplinary assessment of sea-level rise and climate change impacts on the lower Nile delta, Egypt. Sci. Total Environ. 2015, 503-504, 279-288.

18. Ludwig, F.; Vellinga, P. Impacts of Climate Change on Water Resource Management in Egypt and The Netherlands. Contribution to the 42nd Meeting of the Egyptian-Dutch Advisory Panel on Water Management; MWRI: Cairo, Egypt; Alterra: Wageningen, The Netherlands, 2008.

19. Redeker, C.; Kantoush, S.A. The Nile Delta: Urbanizing on Diminishing Resources. Built Environ. 2014, 40, 201-212.

20. Alfiky, A.; Kauleb, G.; Salheena, M. Agricultural fragmentation of the Nile Delta; a modeling approach to measuring agricultural land deterioration in Egyptian Nile Delta. Procedia Environ. Sci. 2012, 14, 79-97. [CrossRef]

21. World Bank. Making the Most of Scarcity: Accountability for Better Water Management Results in the Middle East and North Africa; IBRD: Washington, DC, USA, 2007.

22. El Guindy, S.; El Deen, M.S.; Wolters, W. Integrated policies are a must to face future water scarcity in Egypt. Available online: https://www.wageningenur.nl/de/Publicatie-details.htm?publicationId= publication-way-343230303735 (accessed on 8 April 2016).

23. Hammond, M. The Grand Ethiopian Renaissance Dam and the Blue Nile: Implications for Transboundary Water Governance. Available online: http:/ /www.globalwaterforum.org/2013/02/18/the-grand-ethiopianrenaissance-dam-and-the-blue-nile-implications-for-transboundary-water-governance/ (accessed on 8 April 2016).

24. FAO-IPTRID. Final Report: Rapid Assessment Study Towards Integrated Planning of Irrigation and Drainage in Egypt; FAO: Rome, Italy, 2005.

25. El-Agha, D.; Closas, A.; Molle, F. Survey of Groundwater Use in the Central Part of the Nile Delta, Water and Salt Management in the Nile Delta Project Report No. 6; WMRI: Cairo, Egypt, 2015.

26. Wolters, W.; Ghobrial, N.S.; Bos, M.G. Division of irrigation water in The Fayoum, Egypt. Irrig. Drain. Syst. 1987, 1, 159-172. [CrossRef]

27. Wolters, W.; Habib, Z.; Bhutta, M.N. Forget about crop-demand based canal irrigation in the plains of Pakistan. In Proceedings of Seminar on On-Farm. Salinity, Drainage, and Reclamation; Chaudhry, M.R., Kielen, N.C., Sufi, A.B., Eds.; WAPDA: Lahore, Pakistan, 1997; pp. 67-80.

28. SCP. Responsible Water Management for the Provence Region and Beyond. Available online: http:/ / www.canal-de-provence.com/ (accessed on 23 December 2015).

29. Spangenberg, J.H. Sustainability science: A review, an analysis and some empirical lessons. Environ. Conserv. 2011, 38, 275-287. [CrossRef]

30. Swart, R.; Raskin, P.; Robinson, J. Critical challenges for sustainability science. Science (New York, NY) 2002, 297, 1994-1995. [CrossRef]

31. Scholz, R.W.; Steiner, G. Transdisciplinarity at the crossroads. Sustain. Sci. 2015, 10, 521-526. [CrossRef]

(C) 2016 by the authors; licensee MDPI, Basel, Switzerland. This article is an open access article distributed under the terms and conditions of the Creative Commons Attribution (CC-BY) license (http://creativecommons.org/licenses/by/4.0/). 